\title{
Dose related effects of salbutamol and ipratropium bromide on airway calibre and reactivity in subjects with asthma
}

\author{
JOHN BRITTON, SIMON P HANLEY, HELEN V GARRETT, JOHN W HADFIELD, \\ ANNE E TATTERSFIELD
}

From the Respiratory Medicine Unit, City Hospital, Nottingham

ABSTRACT The relationship between change in airway calibre and change in airway reactivity after administration of bronchodilator drugs has been investigated by comparing the effect of increasing? doses of inhaled salbutamol and ipratropium bromide on the forced expiratory volume in one second $\left(\mathrm{FEV}_{1}\right)$, specific airways conductance (sGaw), and the dose of histamine causing a $20 \%$ fall in FEV $\left(\mathrm{PD}_{20}\right)$ in six subjects with mild asthma. On each of 10 occasions measurements were made of baseline $\mathrm{FEV}_{1}$, sGaw, and $\mathrm{PD}_{20}$ after 15 minutes' rest, and followed one hour later, when the $\mathrm{FEV}_{1}$ ha展 returned to baseline, by a single nebulised dose of salbutamol (placebo, 5, 30, 200 and $1000 \mu \mathrm{g}$ ) or ipratropium (placebo, 5, 30, 200 and $1000 \mu \mathrm{g}$ ) given in random order. Measurements of FEV , sGaw $^{\circ}$ and $\mathrm{PD}_{20}$ were repeated 15 minutes after salbutamol and 40 minutes after ipratropium. Salbutamo and ipratropium caused a similar dose related increase in $\mathrm{FEV}_{1}$ and $\mathrm{sGaw}$, with a mean increase afte $\mathrm{L}_{0}^{2}$ the highest doses of 0.76 and 0.69 litres for $\mathrm{FEV}_{1}$ and 1.15 and $0.96 \mathrm{~s}^{-1} \mathrm{kPa}^{-1}$ for sGaw. Salbutamol also caused a dose related increase in $\mathrm{PD}_{20}$ to a maximum of 2.87 (95\% confidence interval $\left.2 \cdot 18-3 \cdot 55\right)$ doubling doses of histamine after the $1000 \mu \mathrm{g}$ dose, but ipratropium bromide caused no significan $\mathrm{B}$ change in $\mathrm{PD}_{20}$ (maximum increase 0.24 doubling doses, 95\% confidence interval -0.73 to 1.22 ) Thus bronchodilatation after salbutamol was associated with a significantly greater change in airway. reactivity than a similar amount of bronchodilatation after ipratropium bromide. This study show $\overrightarrow{\delta^{\circ}}$ that the relation between change in airway reactivity and bronchodilatation is different for two drugsi with different mechanisms of action, suggesting that change in airway calibre is not a majob determinant of change in airway reactivity with bronchodilator drugs.

Several studies have confirmed an association between increased airway reactivity and diminished airway calibre in subjects with airflow obstruction ${ }^{1-8}$ but the cause of the association is not clear. There are reasons to expect that an increase in airway reactivity would lead to increased airflow obstruction, and vice versa that an increase in airflow obstruction would increase airway reactivity, by a combination of mechanisms..$^{910}$ Alternatively, both airflow obstruction and increased airway reactivity may occur as a result of a common underlying disease process.

Bronchodilator drugs such as $\beta$ agonists, antimuscarinic agents, and methylxanthines have been shown to cause a decrease in airway reactivity in conjunction

Address for reprint requests: Dr John Britton, Respiratory Medicine Unit, City Hospital, Nottingham NG5 IPB.

Accepted 15 December 1987 with bronchodilatation, ${ }^{11-21}$ but whether differenf drugs cause a similar change in airway reactivity for aD given change in airway calibre has not been investigated in dose-response studies. If airway calibre is aN major determinant of airway reactivity a consistent relation might be expected between change in airway calibre and change in reactivity after the administra $\omega$ tion of bronchodilator drugs with different mechan isms of action. This study investigated this relation bye measuring change in airway calibre and reactivity aftere increasing doses of salbutamol and ipratropium ${ }^{p}$ bromide in subjects with mild asthma.

\section{Methods}

SUBJECTS

We studied three men and three women with asthma aged 21-39 years, all non-smokers. All had mild응 
stable asthma with a resting $\mathrm{FEV}_{1}$ over $60 \%$ of the predicted value, an increase in $\mathrm{FEV}_{1}$ of over $15 \%$ after $200 \mu \mathrm{g}$ salbutamol administered by metered dose inhaler, and a provocative dose of histamine causing a $20 \%$ fall in $\mathrm{FEV}_{1}\left(\mathrm{PD}_{20} \mathrm{FEV}_{1}\right)$ of less than $1.8 \mu \mathrm{mol}^{22}$ Two subjects inhaled $\beta$ agonists intermittently as required, four inhaled them regularly every day (maximum dose $800 \mu \mathrm{g}$ daily), and two of these also inhaled steroids regularly. All treatment was withheld for eight hours before each study. The investigation was approved by the City Hospital ethics committee.

\section{METHODS}

$\mathrm{FEV}_{1}$ was measured with a dry bellows spirometer (Vitalograph, Buckingham), the best of three attempts being accepted. Specific airways conductance (sGaw) was measured with the subject panting in a body plethysmograph (Fenyves and Gut, Basel, Switzerland) on line to a microprocessor, and calculated from the mean of six consecutive measurements, each measurement analysing three panting breaths.

Salbutamol and ipratropium bromide solutions for nebulisation were prepared immediately before each study by diluting stock solutions of salbutamol sulphate $5 \mathrm{mg} / \mathrm{ml}$ (Allen and Hanburys) and ipratropium bromide $0.25 \mathrm{mg} / \mathrm{ml}$ (Boehringer Ingleheim) with a $150 \mathrm{mM}$ sodium chloride solution. Airway challenge tests were performed by the method of Yan et al $^{22}$ to a maximum dose of $16 \mu \mathrm{mol}$ of histamine. Inhalation of saline was followed by doubling doses of histamine from $0.03 \mu$ mol until there was a $20 \%$ fall in FEV from the post-saline value. $\mathrm{PD}_{20}$ was estimated by linear interpolation on a log dose-response plot.

\section{PROCEDURE}

Subjects were studied at the same time on 10 different days, on which drug and placebo were administered according to a randomised protocol; this included four doses of ipratropium bromide plus ipratropium placebo (placebo I) and four doses of salbutamol plus salbutamol placebo (placebo $S$ ). The study was double blind, except that the operator was told that the procedure was either for salbutamol/placebo or for ipratropium/placebo so that measurements could be timed appropriately.

On each study day baseline FEV , and sGaw were measured after 15 minutes' rest and, provided that baseline $\mathrm{FEV}_{1}$ was within $10 \%$ of that on day 1 , the first histamine challenge test was carried out. The subject then rested for one hour before the FEV and sGaw measurements were repeated. Salbutamol, ipratropium bromide, or $150 \mathrm{mM}$ saline (placebo) solutions were then administered from an Inspiron nebuliser (Bard Ltd, Sunderland), which when driven by air at 8 litres/min emitted $4 \mathrm{ml}$ of solution during eight minutes of tidal breathing. The nebuliser was primed with $5 \mathrm{ml}$ of solution, at drug concentrations of $1 \cdot 25,7 \cdot 5,50$, and $250 \mu \mathrm{g} / \mathrm{ml}$, so that doses of $5,30,200$, and $1000 \mu \mathrm{g}$ of drug were nebulised. The same nebuliser was used for all studies on each subject. Measurements of sGaw, $F E V_{1}$, and $\mathrm{PD}_{20}$ were repeated 15 minutes after the end of the salbutamol or the salbutamol placebo inhalation and 40 minutes after the ipratropium bromide or the ipratropium placebo inhalation.

\section{DATA ANALYSIS}

Change in $\mathrm{FEV}_{1}$ and sGaw between the baseline value before the first histamine challenge and the post-drug value immediately before the second histamine challenge was calculated for each subject. Change in histamine $\mathrm{PD}_{20}$ between the first and second histamine

Mean (SEM) FEV $(l)$ and sGaw $\left(s^{-1} \mathrm{kPa}^{-1}\right)$ at baseline and before and after drug, geometric mean $P D_{20}(\mu m o l)$ at baseline and after drug, and geometric mean (SEM) change in $P D_{20}\left(\triangle P D_{20}\right)$ between baseline and after drug (doubling doses)

\begin{tabular}{|c|c|c|c|c|c|c|c|c|c|}
\hline \multirow[b]{2}{*}{ Dose ( $\mu g)$} & \multicolumn{3}{|l|}{ Baseline } & \multicolumn{2}{|l|}{ Before drug } & \multicolumn{4}{|l|}{ After drug } \\
\hline & $F E V_{1}$ & sGaw & $P D_{20}$ & $F E V_{l}$ & sGaw & $F E V_{1}$ & sGaw & $P D_{20}$ & $\triangle P D_{20}$ \\
\hline $\begin{array}{l}\text { SALBUTAMOL } \\
\text { Placebo } \\
5 \\
30 \\
200 \\
1000\end{array}$ & $\begin{array}{l}3.10(0.12) \\
3.07(0.13) \\
3.09(0.13) \\
3.02(0.12) \\
3.00(0.16)\end{array}$ & $\begin{array}{l}0.61(0.14) \\
0.66(0.14) \\
0.56(0.06) \\
0.67(0.12) \\
0.62(0.14)\end{array}$ & $\begin{array}{l}0.387 \\
0.395 \\
0.395 \\
0.596 \\
0.490\end{array}$ & $\begin{array}{l}3.15(0.19) \\
3.13(0.15) \\
3.16(0.19) \\
3.03(0.18) \\
3.12(0.16)\end{array}$ & $\begin{array}{l}0.66(0.20) \\
0.74(0.20) \\
0.76(0.19) \\
0.68(0.13) \\
0.71(0.13)\end{array}$ & $\begin{array}{l}2.98(0.26) \\
3.13(0.15) \\
3.42(0.20) \\
3.56(0.21) \\
3.76(0.20)\end{array}$ & $\begin{array}{l}0.60(0.16) \\
0.78(0.16) \\
1.11(0.19) \\
1.40(0.23) \\
1.77(0.22)\end{array}$ & $\begin{array}{l}0.305 \\
0.449 \\
0.814 \\
1.738 \\
3.570\end{array}$ & $\begin{array}{r}-0.34(0.38) \\
0.18(0.16) \\
1.04(0.15) \\
1.54(0.51) \\
2.87(0.27)\end{array}$ \\
\hline $\begin{array}{l}\text { IPRATROPIUM } \\
\text { Placebo } \\
5 \\
30 \\
200 \\
1000\end{array}$ & $\begin{array}{l}3.11(0.16) \\
3.14(0.14) \\
3.06(0.16) \\
3.03(0.17) \\
2.97(0.16)\end{array}$ & $\begin{array}{l}0.68(0.11) \\
0.62(0.11) \\
0.67(0.10) \\
0.61(0.14) \\
0.59(0.12)\end{array}$ & $\begin{array}{l}0.696 \\
0.434 \\
0.741 \\
0.600 \\
0.444\end{array}$ & $\begin{array}{l}3.21(0.21) \\
3.12(0.14) \\
3.06(0.19) \\
2.98(0.15) \\
3.08(0.14)\end{array}$ & $\begin{array}{l}0.71(0.15) \\
0.60(0.10) \\
0.69(0.12) \\
0.58(0.12) \\
0.69(0.14)\end{array}$ & $\begin{array}{l}3.26(0.17) \\
3.28(0.18) \\
3.49(0.21) \\
3.51(0.17) \\
3.66(0.24)\end{array}$ & $\begin{array}{l}0.91(0.17) \\
0.94(0.04) \\
1.29(0.17) \\
1.32(0.20) \\
1.43(0.20)\end{array}$ & $\begin{array}{l}0.608 \\
0.498 \\
0.528 \\
0.749 \\
0.525\end{array}$ & $\begin{array}{r}-0.19(0.25) \\
0.20(0.45) \\
-0.47(0.24) \\
0.32(0.27) \\
0.24(0.38)\end{array}$ \\
\hline Mean & $3.06(0.05)$ & $0.63(0.04)$ & 0.503 & $3 \cdot 10(0 \cdot 07)$ & $0.68(0.06)$ & & & & \\
\hline
\end{tabular}

sGaw-specific airways conductance; $\mathrm{PD}_{20}$ - dose of histamine causing a $20 \%$ fall in $\mathrm{FEV}_{1}$. 


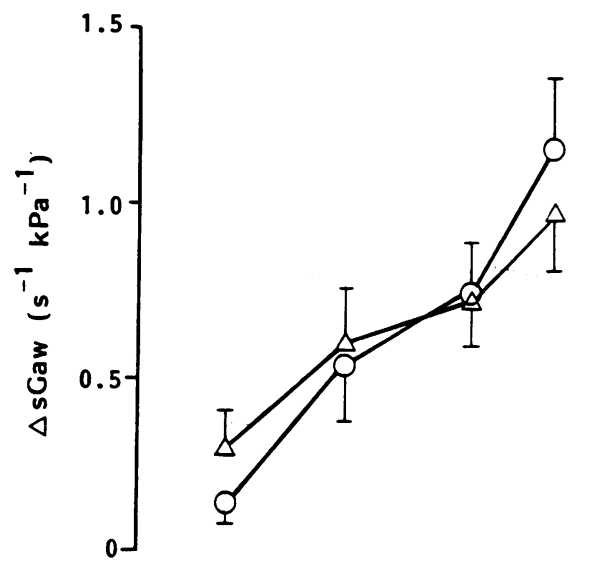

\section{Results}

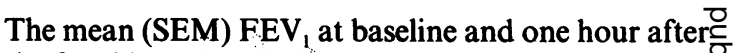
the first histamine challenge (pre-drug value) was $3.06=$ $(0 \cdot 05)$ and $3 \cdot 10(0.07)$ litres. Individual values for FEV $\vec{\perp}$ one hour after the histamine challenge were greater than $90 \%$ of baseline on all 60 study days. The meanes sGaw at baseline and one hour after the first challenge $\vec{\circ}$ was $0.63(0.04)$ and $0.68(0.06) \mathrm{s}^{-1} \mathrm{kPa}^{-1}$ respectively.

Neither of the two placebo inhalations caused a $\bar{\sigma}_{\mathscr{O}}$ significant change in $\mathrm{FEV}_{1}, \mathrm{sGaw}$, or $\mathrm{PD}_{20}$ (table). $\frac{\mathrm{F}}{\mathrm{F}}$ There was a linear increase in $\mathrm{FEV}_{1}$ and $\mathrm{sGaw}$ with $\times$ increasing log dose of salbutamol and ipratropiumce bromide, which was similar and significant for both' drugs $(p<0.001$ and $p<0.01$ for both indices after salbutamol and ipratropium bromide respectively: fig 1). There was a linear increase in $\log \mathbf{P D}_{20}$ with increasing doses of salbutamol $(\mathrm{p}<0.001)$ but not $_{\triangle}$ with ipratropium bromide ( $\mathrm{p}=0.56$ : fig 2$)$, and thiso relationship was significantly different for the two drugs $(\mathrm{p}<0.05)$. The mean increase in $\mathrm{PD}_{20}$ after the $\bigodot_{\odot}$ $1000 \mu \mathrm{g}$ dose of salbutamol was 2.87 doubling doses ${ }^{\circ}$ (95\% confidence interval $2 \cdot 18$ to 3.55 ) and after ipratropium bromide was 0.24 doubling doses $(95 \%$ \ confidence interval -0.73 to 1.22 ). With salbutamolo the increase in $\log \mathrm{PD}_{20}$ was related to increase in $\mathrm{FEV}_{10}$ and sGaw ( $p<0.001$ for both indices), but there was $s_{\Omega}^{\Phi}$ no significant linear relation between change in $\log \Rightarrow$ $\mathrm{PD}_{20}$ and either $\mathrm{FEV}_{1}$ or sGaw for ipratropium 3 bromide ( $p=0.17$ and 0.83 : fig 3 ). The difference between the drugs in this respect was highly significanto for both $\mathrm{FEV}_{1}(\mathrm{p}<0.01)$ and sGaw $(\mathrm{p}<0.001)$.

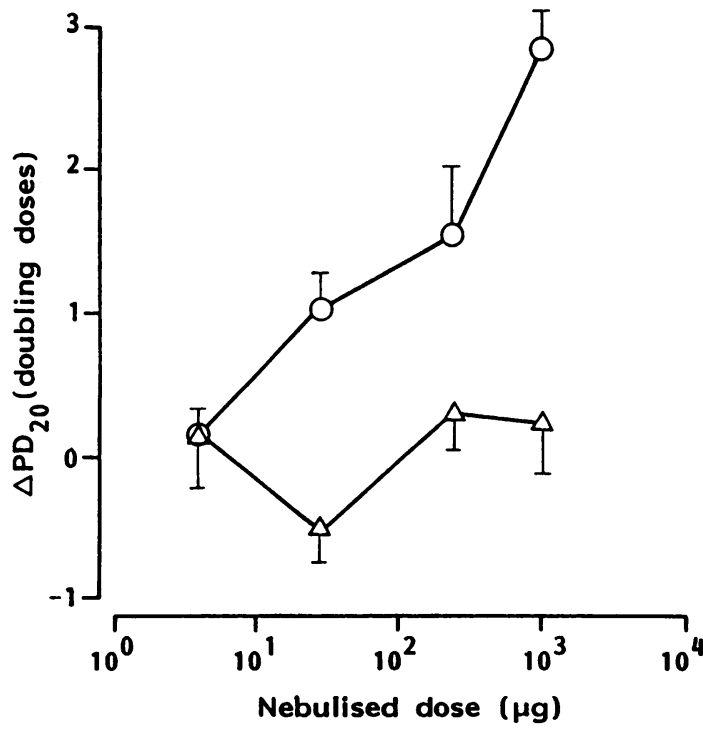

Fig 1 Change in FEV (litres) and specific airways conductance ( $s G a w, s^{-1} \mathrm{KPa}^{-1}$ ) with increasing dose ( $\mu \mathrm{g}$ ) of salbutamol ( $\mathrm{O} \bigcirc$ ) and ipratropium bromide $(\triangle \longrightarrow \triangle)$.

tests was expressed in $\log _{2}$ (doubling dose) units. ${ }^{23}$

Student's paired $t$ test was used to compare baseline FEV $_{1}$ values with values one hour after the first histamine challenge, and to compare baseline $\mathrm{FEV}_{1}$, sGaw, and $\log \mathrm{PD}_{20}$ values with measurements after the salbutamol and ipratropium placebo inhalations. Dose-response gradients for salbutamol and ipratropium bromide were calculated for $\mathrm{FEV}_{1}, \mathrm{sGaw}$, and histamine $P_{20}$ by least squares regression. Log dose-response gradients for $\mathrm{FEV}_{1}$, sGaw, and log histamine $P D_{20}$, and the gradient of change in $\log P D_{20}$ with change in $\mathrm{FEV}_{1}$ and sGaw, were compared between drugs within subjects by Student's $t$ test. A p value of $<0.05$ was considered significant.

Fig 2 Change in histamine $P D_{20}$ ( $\mu$ mol) with increasing dose $(\mu \mathrm{g})$ of salbutamol $(\mathrm{O}$ ) and ipratropium bromide $(\triangle \stackrel{\triangle}{-}$ ). 


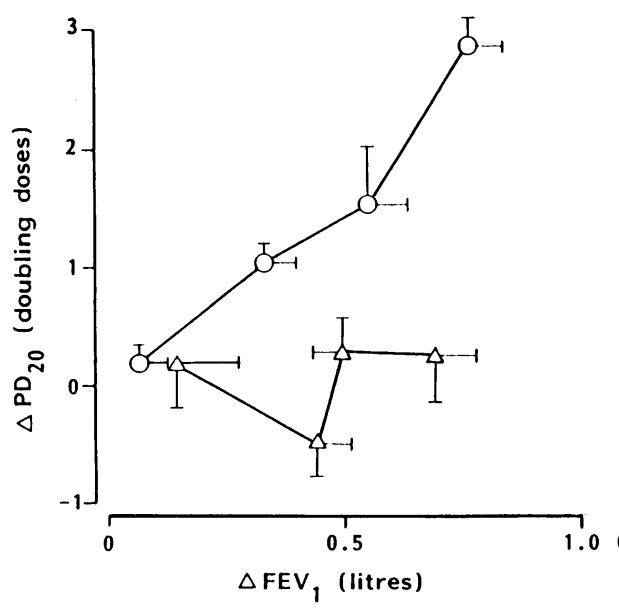

\section{Discussion}

Although a relation between airway reactivity and airway calibre is widely recognised it is still uncertain whether airway hyperreactivity causes bronchoconstriction, whether pre-existing bronchoconstriction causes airway hyperreactivity, or indeed whether both airway hyperreactivity and airflow obstruction are the result of a common underlying disease process. We have investigated the relation between airway calibre and airway reactivity in subjects with mild asthma by comparing changes in the two variables after two bronchodilator drugs with pharmacologically distinct mechanisms of action.

In the subjects with mild asthma we studied significant dose related bronchodilatation occurred after both salbutamol and ipratropium bromide in doses up to $1000 \mu \mathrm{g}$, and within this dose range ipratropium bromide and salbutamol were equipotent. Previous reports have in general suggested that antimuscarinic agents are less effective bronchodilators than $\beta_{2}$ adrenoceptor agonists in patients with asthma, ${ }^{24-26}$ but these studies have compared conventional clinical doses of the two drugs. Higher doses of ipratropium bromide have been shown to cause greater bronchodilatation than conventional doses in patients with both asthma and chronic bronchitis, ${ }^{27-30}$ but the doseresponse relationship of $\beta_{2}$ agonists and ipratropium bromide appear not to have been compared previously in asthmatic subjects.

In our study bronchodilatation with salbutamol was associated with a dose-related decrease in airway reactivity, as described previously with fenoterol. ${ }^{18}$ The maximum increase in geometric mean $P_{20}$ after $1000 \mu \mathrm{g}$ salbutamol was 2.87 doubling doses of histamine, an increase of the same order of magnitude as that reported after single doses of $\beta_{2}$ agonists. ${ }^{11-16}$
We did not, however, find a similar dose related change in airway reactivity after ipratropium bromide, even though a similar degree of bronchodilatation was achieved. We saw no evidence of bronchoconstriction after ipratropium bromide, as has been seen in some studies and attributed to the preservative, benzalkonium chloride,$^{31}$ though, because our measurements were carried out 40 minutes after administration of ipratropium bromide, a relatively short lived episode of bronchoconstriction may have gone undetected. It would not easily explain, however, the lack of association between change in $\mathrm{PD}_{20}$ and $F E V_{1}$ at a time when bronchodilatation had occurred.

Previous studies looking at change in non-specific airway reactivity after single doses of antimuscarinic agents have shown variable results but suggest that the effect is relatively small, ${ }^{23}$ ranging from a mean increase in reactivity to histamine by 0.2 doubling doses in one study ${ }^{32}$ to a maximum reduction in reactivity of 1.5 doubling doses..$^{11-1416}$ None of these studies has looked at the effect of increasing doses of drugs on bronchial reactivity. The maximum increase in $\mathrm{PD}_{20}$ after ipratropium bromide of 0.32 doubling doses in the present study was within the range of increase previously described, ${ }^{23}$ though we were unable to demonstrate a dose-response relationship for change in $\mathrm{PD}_{20}$.

When doses of salbutamol and ipratropium that were equipotent in terms of bronchodilatation were compared salbutamol produced a much greater increase in $\mathrm{PD}_{20}$, suggesting that bronchodilatation per se had little effect on airway reactivity. The fact that bronchodilatation with ipratropium was associated with little if any change in airway reactivity is in keeping with the findings of studies that have looked at the effect of cholinergic agonists rather than antagonists on bronchoconstrictor responses. Pre- 
constriction with methacholine did not alter histamine $\mathrm{PD}_{35}$ sGaw in the study of Chung and Snashall, ${ }^{33}$ nor did it alter the airway response to adenosine in the study of Hardy and colleagues. ${ }^{34}$ Thus, in general, changes in the level of cholinergic stimulation appear to have relatively little effect on airway reactivity to other pharmacological agonists. How far this is true of other constrictor agonists is more debatable. Some studies have shown an interaction between prostaglandin $D_{2}$ and histamine ${ }^{35}$ whereas others have not, ${ }^{34}$ and the same is true for other mediators. ${ }^{337}$ Such interactions as have been seen have been fairly modest, and it is not clear whether they are pharmacological or physiological in origin. ${ }^{34}$

Beta agonists have been shown to be functional antagonists on bronchial smooth muscle in vitro, ${ }^{38}$ causing inhibition irrespective of the contractile stimulus; and this is the likely cause of the reduction in airway reactivity with these drugs in this and other studies. Ipratropium bromide and $\beta$ agonists have different effects on other aspects of airway function that could affect airway reactivity and airway calibre, such as mast cell mediator release, ${ }^{3940}$ mucosal oedema formation, ${ }^{41}$ and mucociliary clearance, ${ }^{42}$ and $\beta$ agonists may modulate neurotransmission in parasympathetic ganglia.$^{38}$ None of these actions, however, as far as they are understood, would easily explain the different effects of $\beta$ agonists and ipratropium on airway dilatation and reactivity.

Our findings raise the important clinical question of whether the effect of salbutamol on airway reactivity offers clinical benefit over and above bronchodilatation alone. Certain drugs, such as calcium antagonists, have been shown to decrease airway reactivity by up to two doubling doses ${ }^{43}$ while causing little if any bronchodilatation. These drugs have been disappointing in practice, however, ${ }^{44}$ suggesting that improvement in bronchial reactivity alone may not be of clinical benefit. Clinical trials are therefore indicated to determine whether at equipotent bronchodilator doses $\beta$ agonists are more effective than antimuscarinic agents in the treatment of asthma and, if they are, to identify the mechanism underlying this advantage.

\section{References}

1 Parker CD, Bilbo RE, Reed C. Methacholine aerosol as test for bronchial asthma. Arch Intern Med 1965; 115:452-8.

2 Klein RC, Salvaggio JE. Nonspecificity of the bronchoconstricting effect of histamine and acetyl-betamethylcholine in patients with obstructive airway disease. J Allergy 1966;37:158-68.

3 De Vries K, Booy-Noord H, Van der Lende $R$, Tammeling GJ, Sluiter HJ, Orie NGM. Reactivity of the airways to exogenous stimuli. Progr Respir Res 1971;6:66-77.

4 Van der Lende R, Visser BF, Wever-Hess J, De Vries K, 으 Orie NGM. Distribution of histamine threshold values $\overline{\bar{\sigma}}$ in a random population. Rev Inst Hyg (Mines) 1973; 28:186-90.

5 Ramsdell JW, Nachtwey FJ, Moser KM. Bronchial $\frac{\varrho}{\Omega}$ hyperreactivity in chronic obstructive bronchitis. $\mathrm{Am}$ क Rev Respir Dis 1982;126:829-32.

6 Ramsdale EH, Morris MM, Roberts RS, Hargreave FE. Bronchial responsiveness to methacholine in chronic $\vec{\omega}$ bronchitis: relationship to airflow obstruction and cold air responsiveness. Thorax 1984;39:912-8.

7 Bahous J, Cartier A, Ouimet G, Pinear L, Malo J-L. Nonallergic bronchial hyperexcitability in chronic $\omega$ bronchitis. Am Rev Respir Dis 1984;129:216-20.

8 Taylor RG, Joyce H, Gross E, Holland F, Pride NB. Bronchial reactivity to inhaled histamine and annual 음 rate of decline in FEV, in male smokers and exsmokers. Thorax 1985;40:9-16.

9 Benson MK. Bronchial hyperreactivity. Br J Dis Chest 1975;69:227-39.

10 Tattersfield AE. Measurement of bronchial reactivity: a $\vec{\omega}$ question of interpretation. Thorax 1981;36:561-5.

11 Casterline CL, Evans R, Ward GW. The effect of atropine and albuterol aerosols on the human bronchial response to histamine. J Allergy Clin Immunol 1976;58:607-13.

12 Cockcroft DW, Killian DN, Mellon JJA, Hargreave FE. ٌّ Protective effect of drugs on histamine-induced $\stackrel{2}{\stackrel{Q}{Q}}$ asthma. Thorax 1977;32:429-37.

13 Nair N, Bewtra A, Townley RG. Protection by Sch-1000윽 and metaproterenol against bronchoconstriction [abstract]. Ann Allergy 1977;38:297.

14 Bandouvakis J, Cartier A, Roberts R, Ryan G, Hargreave FE. The effect of ipratropium and fenoterol on methacholine- and histamine-induced bronchoconstriction. Br J Dis Chest 1981;75:295-305.

15 Salome CM, Schoeffel RE, Woolcock AJ jr. Effect of $\bar{\sigma}$ aerosol and oral fenoterol on histamine and methacholine challenge in asthmatic subjects. Thorax 1981; 36:580-4.

16 Chung F, Morgan B, Keyes SJ, Snashall PD. Histamine 0 dose response relationships in normal and asthmatic subjects. Am Rev Respir Dis 1982;126:849-54.

17 Chung KF, Snashall PD. Methacholine dose response curves in normal and asthmatic man: effect of starting N conductance and pharmacological antagonism. Clin Sci 1984;66:665-73.

18 Salome CM, Schoeffel RE, Yan K, Woolcock AJ. Effect ${ }_{\omega}$ of aerosol fenoterol on the severity of bronchialo hyperreactivity in patients with asthma. Thorax 1983 38:854-8.

19 Ahrens RC, Harris JB, Milavetz G, Annis L, Ries R. Use of bronchial provocation with histamine to compare the pharmacodynamics of inhaled albuterol and $\frac{0}{\circ}$ metaproterenol in patients with asthma. J Allergy Clin $\frac{\mathrm{O}}{\mathbb{\mathrm { Q }}}$
Immunol 1987;79:876-82.

20 McWilliams BC, Menendez R, Kelly HW, Howick J. $\stackrel{\mathbb{Q}}{\Omega}$ Effects of theophylline on inhaled methacholine ando histamine in asthmatic children. Am Rev Respir Dis 1984;130:193-7. 
21 Levene S, McKenzie SA. Protective effect of theophylline on histamine-induced bronchoconstriction in asthmatic children. Br J Clin Pharmacol 1986;21:445-9.

22 Yan K, Salome C, Woolcock AJ. Rapid method for measurement of bronchial responsiveness. Thorax 1983;38:760-5.

23 Tattersfield AE. Effect of beta agonists and anticholinergic drugs on bronchial reactivity. Am Rev Respir Dis 1987;136:S64-8.

24 Crompton GK. A comparison of responses to bronchodilator drugs in chronic bronchitis and chronic asthma. Thorax 1968;23:46-55.

25 Petrie GR, Palmer KNV. Comparison of aerosol ipratropium bromide and satbutamol in chronic bronchitis and asthma. $\mathrm{Br}$ Med J 1975; i:430-2.

26 Lightbody IM, Ingram CG, Legge JS, Johnston RN. Ipratropium bromide, salbutamol and prednisolone in bronchial asthma and chronic bronchitis. $\mathrm{Br} \mathrm{J}$ Dis Chest 1978;72:181-6.

27 Allen CJ, Campbell AH. Dose response of ipratropium bromide assessed by two methods. Thorax 1979; 34:137-9.

28 Gomm SA, Keaney NP, Hunt LP, Allen SC, Stretton TB. Dose response comparison of ipratropium bromide from a metered dose inhaler.and by jet nebulisation. Thorax 1983;38:297-301.

29 Hockley B, Johnson NMcI. A comparison of three high doses of ipratropium bromide in chronic asthma. $\mathrm{Br} J$ Dis Chest 1985;79:379-84.

30 Lenney W, Evans NAP. Nebulised salbutamol and ipratropium bromide in asthmatic children. $\mathrm{Br} J$ Dis Chest 1986;80:59-64.

31 Beasley CRW, Rafferty P, Holgate ST. Bronchoconstrictor properties of preservatives in ipratropium bromide (Atrovent) nebuliser solution. $\mathrm{Br}$ Med J 1987;294:1197-8.

32 Woenne R, Kattan M, Orange RP, Levison H. Bronchial hyperreactivity to histamine and methacholine in asthmatic children after inhalation of $\mathrm{SCH} 1000$ and chlorpheniramine maleate. J Allergy Clin Immunol 1978; 62:119-24.
33 Chung KF, Snashall PD. Effect of prior bronchoconstriction on the airway response to histamine in normal subjects. Thorax 1984;39:40-5.

34 Hardy CC, Bradding P, Robinson C, Holgate ST. The combined effects of two pairs of mediators, adenosine with methacholine and prostaglandin $D_{2}$ with histamine, on airway calibre in asthma. Clin Sci 1986; 71:385-92.

35 Fuller RW, Dixon CMS, Dollery CT, Barnes PJ. Prostaglandin $D_{2}$ potentiates airway responsiveness to histamine and methacholine. Am Rev Respir Dis 1986;133:252-4.

36 Walters EH, Parrish RW, Bevan C, Smith AP. Induction of bronchial hypersensitivity: evidence for a role for prostaglandins. Thorax 1981;36:571-4.

37 Heaton RW, Henderson AF, Dunlop LS, Costello JF. The influence of pretreatment with prostaglandin $F_{2 \alpha}$ on bronchial sensitivity to inhaled histamine and methacholine in normal subjects. Br J Dis Chest 1984;78:168-73.

38 Barnes PJ. Neural control of human airways in health and disease. Am Rev Respir Dis 1986;134:1289-314.

39 Peters SP, Schulman ES, Schleimer RP, Macglashan DW, Newball HH, Lichtenstein LM. Dispersed human lung mast cells. Pharmacological aspects and comparison with human lung tissue fragments. Am Rev Respir Dis 1982;126:1034-9.

40 Church MK, Pao G-JK, Holgate ST. Inhibition of IgEdependent histamine release from dispersed human lung mast cells by albuterol and cromolyn sodium. Am Rev Respir Dis (in press).

41 Persson CGA, Ekman M, Erjefalt I. Terbutaline preventing permeability effects of histamine in the lung. Acta Pharmacol Toxicol 1978;42:395-7.

42 Wanner A. Alteration of tracheal mucociliary transport in airway disease. Chest 1981;80:867-70.

43 Barnes PJ. Clinical studies with calcium antagonists in asthma. Br J Clin Pharmacol 1985;20:289-98S.

44 Patakas D, Maniki E, Tsara V, Dascalopoulou E. Nifedipine treatment of patients with bronchial asthma. J Allergy Clin Immunol 1987;79:959-63. 